\title{
Cyclic behavior of late quaternary alluvial soil along Indo-Gangetic Plain: Northern India
}

\author{
Sambit Prasanajit Naik, Nihar Ranjan Patra* and Javed N. Malik
}

*Correspondence: nrpatra@iitk.ac.in Department of Civil Engineering, Indian Institute of Technology Kanpur, Kanur 208016, UP, India

\begin{abstract}
The A.D. 1803 and 1934 Bihar-Nepal border earthquake affected Indo-Gangetic Plain with evidences of liquefaction in cities like Patna, Varanasi, Agra, and Delhi in historical past. Recent strong shaking all along the Indo-Gangetic Plains and seismic induced damage to the buildings in Bihar during $M_{w} 7.8$ Gorkha earthquake raises the concern for site specific liquefaction potential estimation of alluvial soils. Cyclic triaxial tests were conducted on soil samples from Kanpur, Allahabad, Patna city to know the cyclic behavior, estimate the dynamic soil properties and the effect of relative density, confining pressure and frequency of loading on the cyclic behavior of the soil tested. The test results indicate the cyclic strength of Allahabad soil is less than Patna and Kanpur soil. The Allahabad soil with $80 \%$ sand, $10 \%$ silt and clay each is more prone to liquefaction than Kanpur soil (82\% silt, $16 \%$ clay and 2\% sand) and Patna soil (10\% Kankar, 95\% sand, $5 \%$ silt). This study indicates soils having sand with silt percentage are more liquefiable than clean sand or silty soil. It can be concluded that the soil of Allahabad and Patna city is more prone to liquefaction than Kanpur soil.
\end{abstract}

Keywords: Indo Gangetic Plain, Cyclic triaxial, Liquefaction, Shear modulus, Damping ratio

\section{Introduction}

Historical records and recent geological studies suggest that the 1803 A.D. $\left(\mathrm{M}_{\mathrm{w}} 7.7\right)$ and 1934 Bihar-Nepal border earthquake $\left(M_{w} 8.1\right)$ caused severe damage along IndoGangetic Plains [26]. There are evidences of sand boils and sand blows during A.D.1803, A.D. 1833 and 1934 Bihar Nepal Border earthquakes along Indo-Gangetic Pains. During the 2015 Gorkha earthquake $\left(M_{w} 7.8\right)$, the areas of Uttar Pradesh, Bihar undergoes severe shaking and some parts of Bihar Plain undergoes liquefaction [39]. The effects of subsurface conditions of ground failure were investigated through one dimensional and two dimensional ground response analysis by few authors [20, 24, 28-30, 32, 33, 40, 41] for the alluvial soil of Indo-Gangetic Plains. But, there is no detailed experimental study for liquefaction potential evaluation of the study area is reported yet. Various studies have been carried out on the cyclic behavior of fine grained soil, which indicates clean sand is more prone to liquefaction than sand with silt content $[4-10,13,21,25,29,34$, 37, 46]. A number of laboratory and field techniques are available to evaluate the liquefaction potential of soil [15]. Strain controlled tests on sand and silty sand has been author(s) and the source, provide a link to the Creative Commons licence, and indicate if changes were made. The images or other third party material in this article are included in the article's Creative Commons licence, unless indicated otherwise in a credit line to the material. If material is not included in the article's Creative Commons licence and your intended use is not permitted by statutory regulation or exceeds the permitted use, you will need to obtain permission directly from the copyright holder. To view a copy of this licence, visit http:// creativecommons.org/licenses/by/4.0/. 
reported by several researchers $[3-6,10,12,15-19,21,22,24,28,29,29-32,35,37,43$, 44]. The effect of relative density, effective stress, and frequency on the cyclic response of liquefiable soils has been well understood by Dash and Sitharam [6], Govinda Raju and Sitharam [14] and Krim et al. [23]. The purpose of this paper is to investigate and evaluate the cyclic behavior of the alluvial soil of different characteristics under cyclic conditions which is not reported in any literature for the Indo-Gangetic Plain. Soil samples from three cities along Indo-Gangetic plain viz. Kanpur, Allahabad and Patna are used to study the cyclic behavior. The effects of relative density, strain amplitude, effective stress, loading frequency of liquefaction potential of soils has also been studied. The dynamic soil properties such as shear modulus and damping ratios of alluvial soil have been evaluated for Kanpur soil, Allahabad soil and Patna soil. Also, an empirical relationship between Cyclic Resistance Ratio (CRR) with the effective confining pressure have been developed for Kanpur soil, Allahabad soil and Patna soil for relative density of $35-70 \%$ which is not available for the alluvial soils of Indo-Gangetic Plains. The reported results will be useful in the proper seismic hazard assessment and designing of seismic resistant structures.

\section{Testing program and test procedures}

\section{Site selection, sample characteristics, sample preparation and test programs}

The selection of sites has been done based on Seismic Microzonation Map of India, where all cities are coming under seismic zone III-IV and have experienced moderate to large magnitude earthquakes (Fig. 1). These areas also have seismic threats from the front thrust of the Himalayas, which is able to generate an earthquake of magnitude over 7.5. In this study, soils samples were collected from Kanpur city, Allahabad city and Patna city along Indo- Gangetic plain. The map showing the historical and recent earthquakes that affected the Indo-Gangetic plain and the locations of study area are shown in Fig. 1.






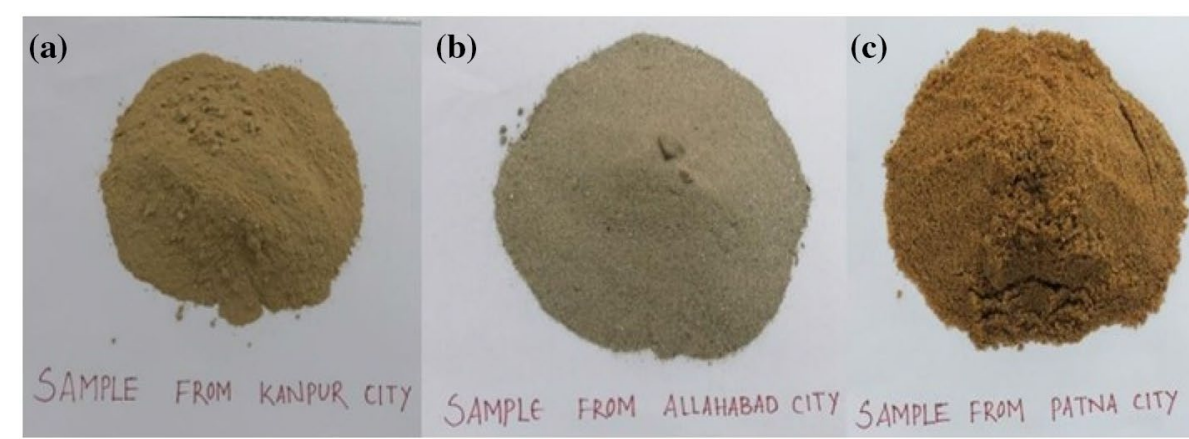

Fig. 2 Photographic view of the soil samples from (a) IIT Kanpur Campus soil of Kanpur city, b Jagadishpur site of Allahabad city and (c) IIT Patna campus soil of Patna city along Indo-Gangetic Plain

Table 1 Index properties of the soil used in this present study

\begin{tabular}{llll}
\hline Index properties & \multicolumn{2}{l}{ Location of soil sample } & \\
\cline { 2 - 4 } & Kanpur & Allahabad & Patna \\
\hline Specific gravity & 2.66 & 2.65 & 2.60 \\
Gravel (\%) & $\mathrm{Nil}$ & $\mathrm{Nil}$ & 10 \\
Sand size (\%) & 2 & 80 & 94.52 \\
Silt size (\%) & 82 & 10 & 5.52 \\
Clay size (\%) & 16 & 10 & 0 \\
Liquid limit (\%) & 26.5 & $\mathrm{Nil}$ & $\mathrm{Nil}$ \\
Plastic limit & 19.41 & $\mathrm{Nil}$ & $\mathrm{Nil}$ \\
Plasticity index (\%) & 7.085 & $\mathrm{Nil}$ & $\mathrm{Nil}$ \\
Maximum void ratio (emax) & 1.22 & 0.9602 & 1.02 \\
Minimum void ratio (emin) & 0.34 & 0.8269 & 0.98 \\
\hline
\end{tabular}

Figure 2 shows the pictorial view of soil samples used in this study. The soil samples collected from IIT Kanpur campus, Kanpur are situated within the flood plain deposits of the Ganga River. The soil samples collected from Jagadishpur site of Allahabad city are from the interfluves of Ganga and Yamuna River. The soil samples collected from IIT Patna sites, Patna city are situated on the bank of Son River. On the basis of SPT-N values and shear wave velocity data, the loose soil deposits below the water table were taken for preparation of remolded soil samples for cyclic triaxial test. The soil samples from IIT Kanpur campus site of Kanpur city and Jagadishpur site of Allahabad city were collected at a depth of $7.5 \mathrm{~m}$ each and are mainly silty sand, fine sand, respectively. However, the soil samples from IIT Patna site of Patna city, are clean sand and were collected at a depth of $6 \mathrm{~m}$. The index properties for the individual soil samples used in this study are determined in accordance with ASTM D2487-11 [1] and are presented in Table 1. The grain size distribution curves for soil samples from IITK campus, Jagadishpur and IIT Patna are shown in Fig. 3. The soils from the IIT Kanpur campus site consists of $18 \%$ sand, and $82 \%$ silt and is classified as silty sand. The soil at Jagadishpur consists of more than $80 \%$ sand and is classified as fine sand with significant mica content. The soil from IIT Patna consists of more than $90 \%$ sand and is classified as clean sand. The void ratio for the sample preparation has been selected based on grain size. Due to the presence 


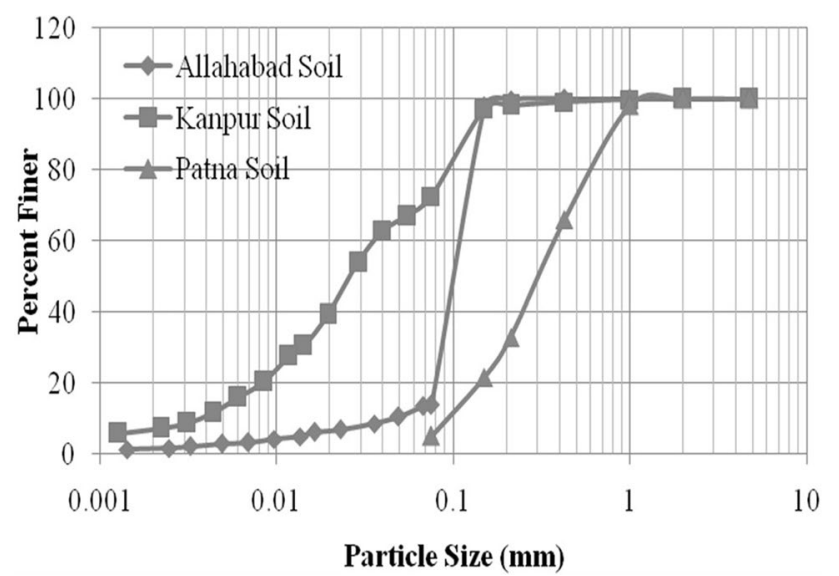

Fig. 3 Grain size distribution of soils from Kanpur city (IITK campus soil), Allahabad city (Jagadishpur site) and Patna city (IIT Patna campus soil) of Indo-Gangetic Plain

of silty soil, the vacuum ratio of the IITK campus soil was determined from the proctor compaction test. The void ratios of soils from Jagadishpur site of Allahabad city and IIT Patna campus of Patna city were determined from the vibration compaction test. The maximum and minimum void ratio obtained from proctor compaction and vibration table tests are as per the procedure given in IS: 2729 standard similar to ASTM 4233 and ASTM 4254-2000. Remoulded samples were prepared using moist tamping under compaction methods in five layers $[14,17]$. Sand samples were prepared with moist tamping using vacuum. Undrained cyclic triaxial tests (strain-controlled) were carried out on soils to evaluate the cyclic behavior of the soil (Fig. 4). All tests were performed according to ASTM D5311 [2] and ASTM D 3999 [3] standards. Soil samples of $100 \mathrm{~mm}$ height and $50 \mathrm{~mm}$ diameter were tested at a different relative density (35\%, 50\% and 70\%), effective confining pressure $(80,100$ and $125 \mathrm{kPa})$ and frequency change of $0.3,0.5$ and $1 \mathrm{~Hz}$ at different shear strain amplitude. The strain amplitude was chosen on the basis of the strain range supplied by Ishihara [16] and taking into account the seismic scenario of the study area. The frequency ranges were selected on the basis of the frequency range for earthquake loading provided by Ishihara [16] and Seed et al. [38], which indicate the frequency of $1 \mathrm{~Hz}$ corresponds to an earthquake of $M_{w}$ 7. The effects of relative density, strain amplitude, effective confining pressure and applied loading frequency on liquefaction potential of soil have been studied. The detailed testing program showing all the parameters is given in Table 2. All the tests have been performed with harmonic sine waves. The soil samples were saturated by applying the back pressure until the pore pressure parameter (B value) reaches 0.95 with the controlling the effective confining pressure of $20 \mathrm{kPa}$. After achieving the B value of more than $95 \%$ the samples were consolidated isotropically and sheared with a constant confining pressure.

\section{Results and discussions}

\section{Development of deviatoric stress and pore water pressure}

The variations of deviatoric stress and pore water pressure with loading cycles, variation of deviator stress with shear strain and the mean effective stress have been 


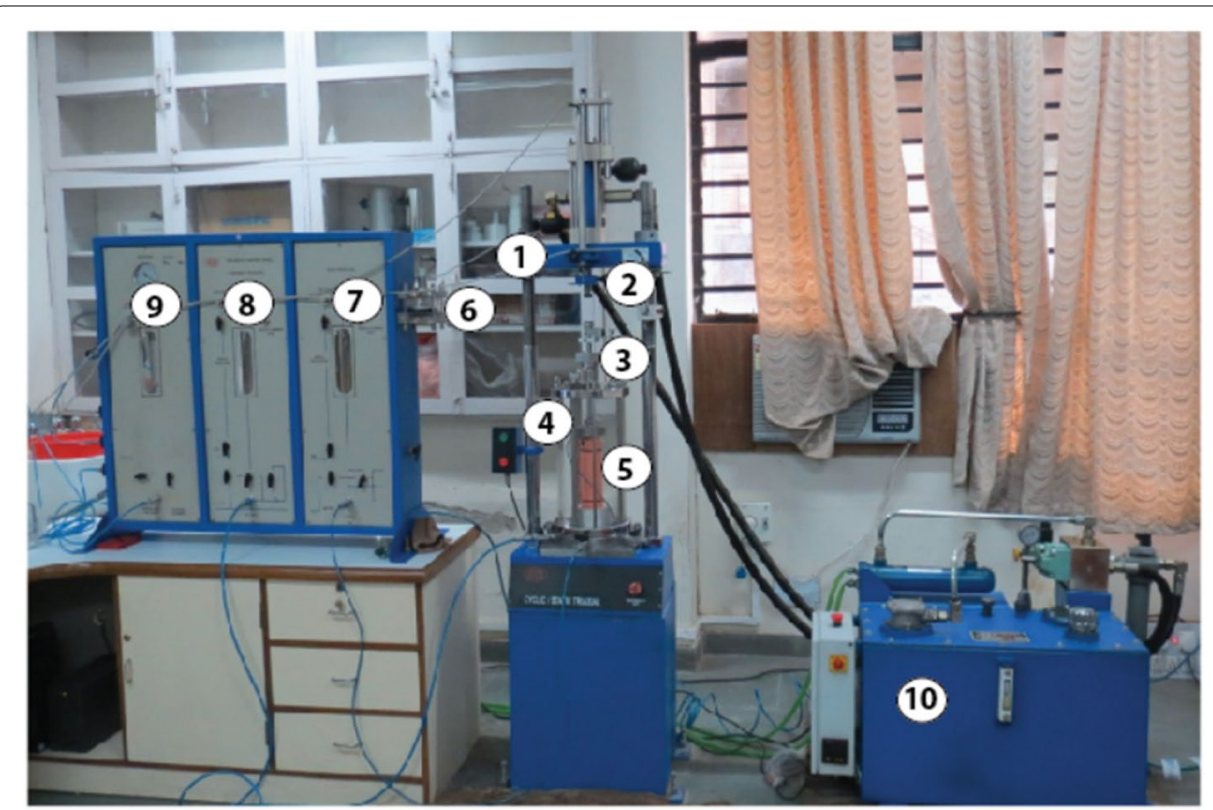

$1=$ Cyclic Triaxial loading frame, $2=$ Load cell, $3=L V D T, 4=$ Triaxial cell, $5=$ Soil Sample, $6=$ Volume Change device $7=$ Pore pressure control, $8=$ Cell pressure control, $9=$ Vaccume control, $10=$ Power pack

Fig. 4 Pictorial view of the testing apparatus used for the present study. Different number indicates the different parts of the Cyclic triaxial machine

Table 2 Program adopted for the cyclic triaxial testing

\begin{tabular}{|c|c|c|c|c|c|}
\hline SI. No. & Material tested & Relative density (\%) & $\begin{array}{l}\text { Confining } \\
\text { pressure } \\
(\mathrm{kPa})\end{array}$ & Frequency $(\mathrm{Hz})$ & Shear strain amplitude (\%) \\
\hline 1 & Kanpur soil & $35,50,70 \%$ & 100 & 1.0 & $0.4,0.6,0.8,0.9,1.0,1.25$ \\
\hline 2 & Allahabad soil & $35,50,70 \%$ & 100 & 1.0 & $0.20,0.30,0.40,0.60$ and 0.80 \\
\hline 3 & Patna soil & $35,50,70 \%$ & 100 & 1.0 & $\begin{array}{l}0.20,0.30,0.40,0.50,0.60 \\
\text { and } 0.80\end{array}$ \\
\hline 4 & Kanpur soil & $50 \%$ & $80,100,125$ & 1.0 & $0.20,0.30,0.40,0.60$ and 0.80 \\
\hline 5 & Allahabad Soil & $50 \%$ & $80,100,125$ & 1.0 & $0.20,0.30,0.40,0.60$ and 0.80 \\
\hline 6 & Kanpur soil & $50 \%$ & 100 & $0.3,0.5$ and 1 & $0.20,0.30,0.40,0.60$ and 0.80 \\
\hline 7 & Allahabad soil & $50 \%$ & 100 & $0.3,0.5$ and 1 & $0.20,0.30,0.40,0.60$ and 0.80 \\
\hline
\end{tabular}

plotted for all the soils tested. Typical test results for the soil samples from Allahabad city are shown in Figs. 5a, b and 6a, b. During cyclic loading, as the number of loading cycle increase, the deviator stress gradually decreases to zero with gradual increase in the pore water pressure. Such condition is observed at about 15-800 cycles for Kanpur soil, 8-70 for Allahabad soil and 10-120 cycles for Patna soil, respectively, for all confining pressures, densities and strain amplitudes (Table 3). The hysteresis loop of the test results flattens out as the loading cycles increase (Fig. 6a). With the loading cycle increases, the effective stress path moves to the left, which indicates an increase in the pore pressure ratio within the soil sample as well as the reduction of mobilized shear strength (Fig. 6b). The present study compared with the reported result of Dobry et al. [12], Talaganov [43], Govinda Raju and Sitharam [14], Raghunandan 


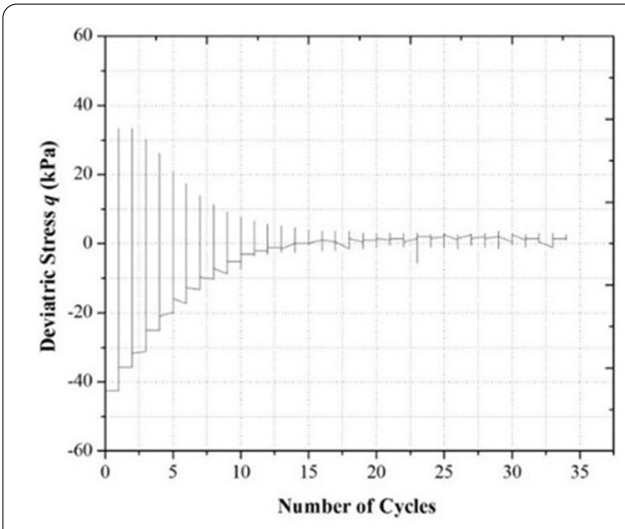

(a)

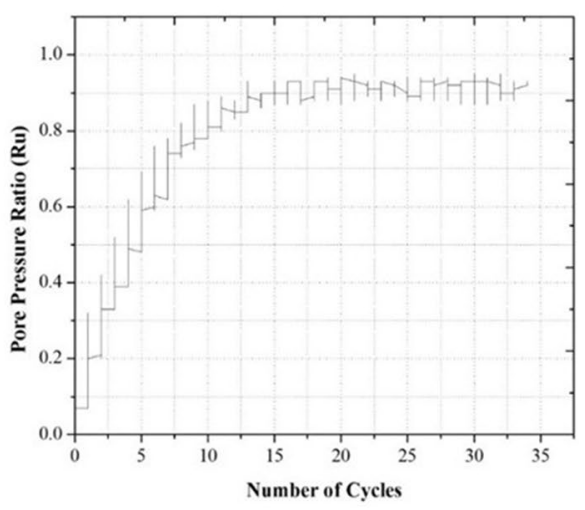

(b)

Fig. 5 a Variation of deviator stress with number of loading cycles. $\mathbf{b}$ Variation of pore pressure ratio with number of cycles (Allahabad soil, RD $=50 \%$ and shear strain amplitude $=0.30 \%$ )

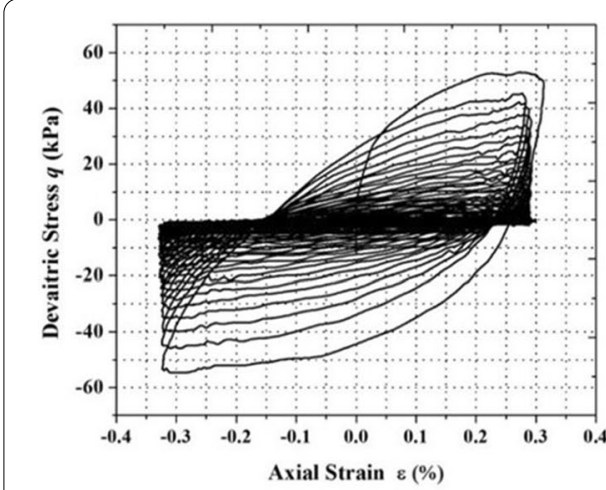

(a)

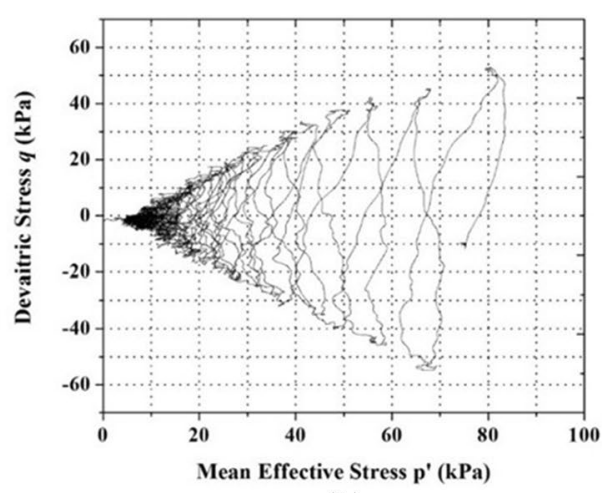

(b)

Fig. 6 a Stress strain relationship. $\mathbf{b}$ Stress path of Allahabad soil $(R D=50 \%$, effective confining pressure $=$ $100 \mathrm{kPa}, \mathrm{f}=1 \mathrm{~Hz}$, shear strain amplitude $=0.30 \%)$

and Juneja [35], Muley et al. [30] (Table 4). Kanpur soil is having a higher percentage of silt and clay fraction and is showing higher resistance of liquefaction as compared to Allahabad, Patna, Bhuj, Assam, Ahmedabad soil. Kanpur soil shows similar results like Talaganov [43] and Raghunandan and Juneja [35]. This is because the soils tested exhibit the same characteristics with a higher percentage of fines and a higher plasticity index. Patna soil shows almost similar behavior in Bhuj, Assam, Ahmedabad soils because of the higher percentage of sand. But, Allahabad soil shows higher liquefaction susceptibility with lower number cycles. This is due to the fact that the Allahabad soil has a higher percent of sand with $10 \%$ of silt. The results of Allahabad soil well correlate with the previous studies by Naeini and Baziar [31] and Boulanger and Idriss [7] which suggests that sand with a higher percentage of silt/clay is more susceptible to liquefaction than clean sand.

\section{Effect of relative density on cyclic behavior of soil}

The variations of axial shear strain with loading cycles have been plotted for Kanpur soil, Allahabad soil and Patna soil for different relative density (Fig. 7a-d). The 
Table 3 Number of cycles required for initial liquefaction of soils from Kanpur, Allahabad and Patna

\begin{tabular}{|c|c|c|c|c|c|}
\hline $\begin{array}{l}\text { Location of } \\
\text { Soil sample }\end{array}$ & $\begin{array}{l}\text { Relative } \\
\text { density (\%) }\end{array}$ & $\begin{array}{l}\text { Effective } \\
\text { stress (kPa) }\end{array}$ & $\begin{array}{l}\text { Frequency } \\
(\mathrm{Hz})\end{array}$ & Strain amplitude & $\begin{array}{l}\text { Number cycle } \\
\text { for initial } \\
\text { liquefaction }\end{array}$ \\
\hline \multirow[t]{7}{*}{ Kanpur } & 35 & 100 & 1 & $0.4,0.6,0.8$ & $50,28,15$ \\
\hline & 50 & 80 & 1 & $0.4,0.6,0.8$ & $60,22,12$ \\
\hline & & 100 & 0.3 & $0.4,0.6,0.8$ & $290,110,45$ \\
\hline & & & 0.5 & $0.4,0.6,0.8$ & $110,80,43$ \\
\hline & & & 1 & $0.4,0.6,0.8$ & $71,32,20$ \\
\hline & & 125 & 1 & $0.4,0.6,0.8$ & $89,40,30$ \\
\hline & 70 & 100 & 1 & $0.8,0.9,1,1.2$ & $800,400,120,70$ \\
\hline \multirow[t]{7}{*}{ Allahabad } & 35 & 100 & 1 & $0.2,0.3,0.4,0.6$ & $30,22,15$ and 8 \\
\hline & 50 & 80 & 1 & $0.2,0.3,0.4,0.6$ & $55,35,23$ and 16 \\
\hline & & 100 & 0.3 & $0.2,0.3,0.4,0.6$ & $90,46,23$ \\
\hline & & & 0.5 & $0.2,0.3,0.4$ and 0.6 & $95,65,30$ \\
\hline & & & 1 & $0.2,0.3,0.4$ and 0.6 & $65,40,20,11$ \\
\hline & & 125 & 1 & $0.2,0.3,0.4$ and 0.6 & $100,65,40$ and 25 \\
\hline & 70 & 100 & 1 & $0.4,0.6$ and 0.8 & $25,15,8$ \\
\hline \multirow[t]{3}{*}{ Patna } & 35 & 100 & 1 & $0.2,0.3,0.4$ and 0.5 & $100,47,20$ and 12 \\
\hline & 50 & 100 & 1 & $0.2,0.3,0.4$ and 0.5 & $116,60,25$ and 18 \\
\hline & 70 & 100 & 1 & $0.2,0.4,0.6$ and 0.8 & $120,40,27$ and 22 \\
\hline
\end{tabular}

Table 4 Comparison of liquefaction potential of present study with previous studies

\begin{tabular}{lllc}
\hline Authors & Soil type & $\begin{array}{l}\text { Relative density } \\
\text { (\%) }\end{array}$ & $\begin{array}{l}\text { Number of cycles for } \\
\text { initial liquefaction }\end{array}$ \\
\hline Dobry (1985) & Sand & $45-80$ & $100-1000$ \\
K. V. Talaganov (1996) & Sand & $40-80$ & $1-400$ \\
Govindraju (2005) & Bhuj sand & $8.9-80$ & $6-120$ \\
Govindraju (2005) & Ahmedabad sand & $30-70$ & $8-650$ \\
Govindraju (2005) & Assam sand & $20-75$ & $9-330$ \\
Raghunandan and Juneja (2010) & Bombay soil & $30-70$ & $32-500$ \\
Muley et al. (2012) & Solani sand & $35-50$ & $4-20$ \\
Omarov (2010) & Ottawa sand & $30-50$ & $10-100$ \\
Present study & Kanpur soil & $30-70$ & $12-800$ \\
Present study & Allahabad soil & $30-70$ & $8-100$ \\
Present study & Patna soil & $30-70$ & $12-120$ \\
\hline
\end{tabular}

results indicate the cycles caused initial liquefaction of the soil is dependent on strain amplitude and relative density. It has been observed that at the higher strain amplitude, liquefaction occurs at lower cycles. Whereas, for the lower strain amplitude, liquefaction occurs at a higher number of loading cycles. By increasing the relative density from 35 to $70 \%$, the number of loading cycles required for initial liquefaction increases. The increase in the loading cycles is about $20 \%$ to $30 \%, 15 \%$ to $36 \%$ and $10 \%$ to $30 \%$ higher in Kanpur soil, Allahabad soil and Patna soil, respectively. The increment in the loading cycles varies from 10 to $65 \%, 6 \%$ to $58 \%$ and $17 \%$ to $85 \%$ for relative densities of $35 \%, 50 \%$ and $70 \%$, respectively for all strain amplitudes. Typical 


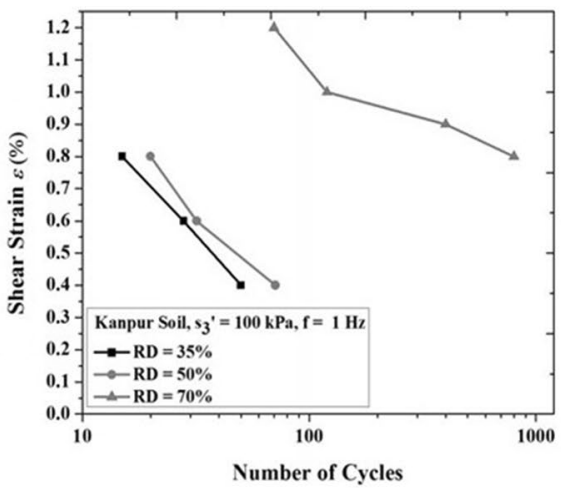

(a)

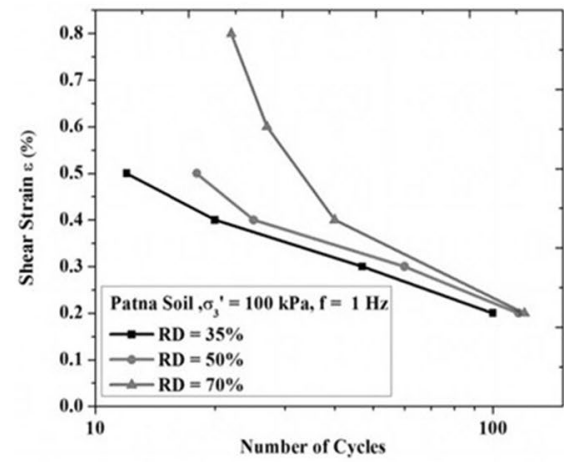

(c)

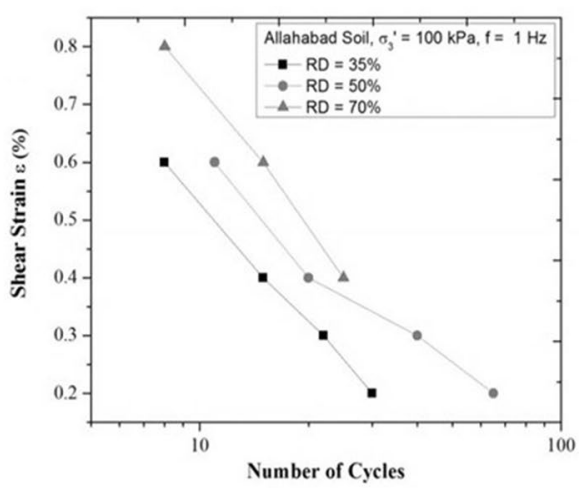

(b)

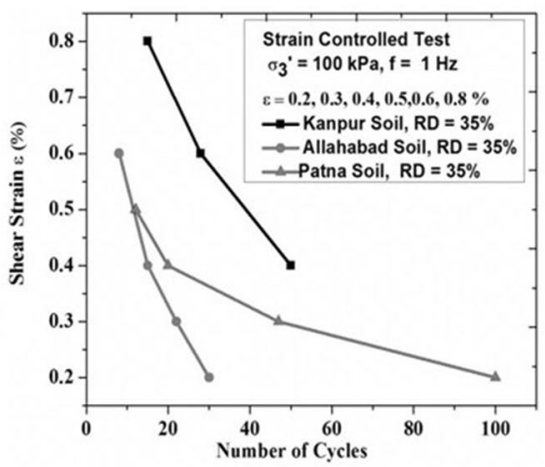

(d)

Fig. 7 Relationship between axial shear strain amplitude and number of cycles for initial liquefaction a for Kanpur soil, $\mathbf{b}$ for Allahabad soil, c for Patna soil, and $\mathbf{d}$ Comparative study of axial shear strain and number of cycles for initial liquefaction for Kanpur soil, Allahabad soil and Patna soil with various strain amplitudes with relative density of $35 \%$ and frequency of $1 \mathrm{~Hz}$

diagram showing the variation of loading cycles required for initiation of liquefaction for Kanpur soil, Allahabad soil and Patna soil is shown in Fig. 7d.

\section{Effect of confining pressure on cyclic behavior of soil}

The influence of effective confining pressure on liquefaction potential of soil has been studied for Kanpur soil and Allahabad soil. Undrained cyclic tests have been carried out on Kanpur and Allahabad soils with effective confining pressures of $80 \mathrm{kPa}, 100 \mathrm{kPa}$ and $125 \mathrm{kPa}$ for relative density of $50 \%$ and a frequency of $1 \mathrm{~Hz}$. The number of loading cycles required for initial liquefaction varies from 12 to 60,20 to 71, 30 to 89 for Kanpur soil, whereas for Allahabad soil, the initiation of liquefaction is observed at 16-55, 11-65, 25-100 loading cycles. For both the sites, the number of loading cycles required for initial liquefaction increases with an increase of effective confining pressure of $80 \mathrm{kPa}$ to $125 \mathrm{kPa}$. The percentage of increase in the number of loading cycles required for initial liquefaction is about $18-67 \%$ and $30-100 \%$ of Kanpur soil and Allahabad soil, respectively (Fig. 8a). 


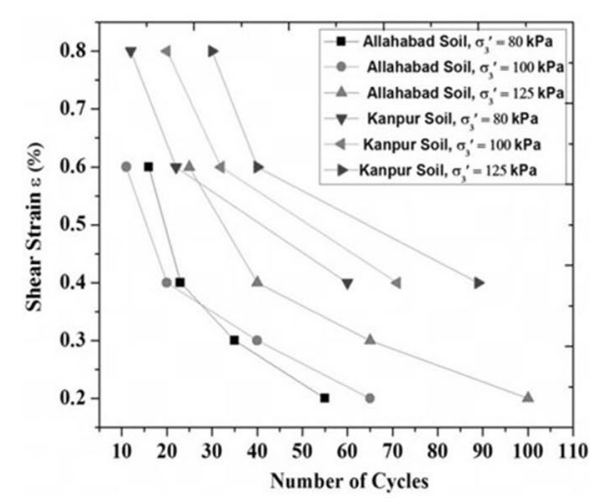

(a)

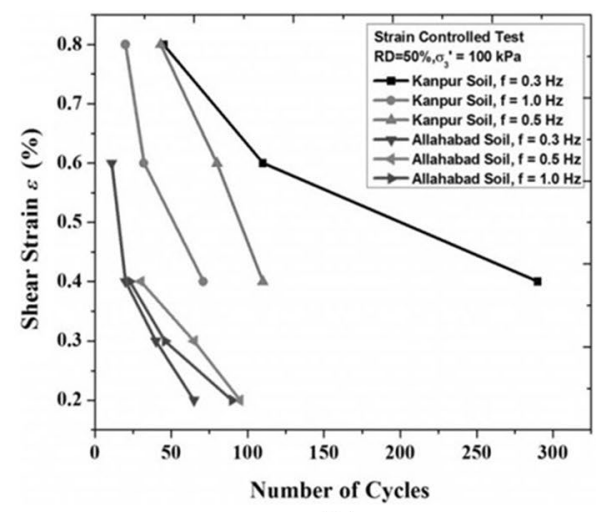

(b)

Fig. 8 Comparative study of shear strain and number of cycles for initial liquefaction for Kanpur and Allahabad soil. a Effective confining pressure $=80 \mathrm{kPa}, 100 \mathrm{kPa}$, and $125 \mathrm{kPa}, \mathrm{RD}=50 \%$ and frequency $=1$ $\mathrm{Hz}$. b Applied frequency $=0.3 \mathrm{~Hz}, 0.5 \mathrm{~Hz}$ and $1 \mathrm{~Hz}, \mathrm{RD}=50 \%$ and effective confining pressure $=100 \mathrm{kPa}$

\section{Effect of frequency on cyclic behavior of soil}

Strain controlled tests were conducted on Kanpur and Allahabad soil with varying frequency from $0.3 \mathrm{~Hz}, 0.5 \mathrm{~Hz}$ and $1 \mathrm{~Hz}$ with a relative density of $50 \%$ and the effective confining pressure of $100 \mathrm{kPa}$. The number of cycles required for initiation of liquefaction varies from 45 to 290, 43 to 110 and 20 to 71, respectively. For the Allahabad soil, the numbers of cycles required for initial liquefaction are 30 to 95,23 to 90 and 11 to 65 for the all the applied frequency ranges. The number of cycles needed to initiate liquefaction decreases with the frequency increase from $0.3 \mathrm{~Hz}$ to $1 \mathrm{~Hz}$. The decrease in number of loading cycles is about $45 \%$ to $163 \%$ and $5 \%$ to $30 \%$ with an increase in applied frequency from $0.3 \mathrm{~Hz}$ to $1.0 \mathrm{~Hz}$ for Kanpur soil and Allahabad soil, respectively (Fig. 8b).

\section{Excess pore pressure development during cyclic loading}

The excess pore pressure development during the cyclic loading has been studied for Kanpur soil, Allahabad soil and Patna soil for different relative density (35\%, 50\%, 70\%), effective confining pressure $(80 \mathrm{kPa}, 100 \mathrm{kPa}, 125 \mathrm{kPa})$ and frequency applied $(0.3 \mathrm{~Hz}$, $0.5 \mathrm{~Hz}, 1.0 \mathrm{~Hz})$. The pore water pressure ratio has been plotted with a cyclic ratio $(\mathrm{N} /$ $\mathrm{NL})$. The number of loading cycles $(\mathrm{N})$ has been normalized by dividing the number of loading cycles with NL, which is the cumulative number of cycles needed for the excess pore water pressure development. Figure 9 shows the effect of relative density on pore water pressure development for Kanpur soil, Allahabad soil and Patna soil. For a specific relative density and number of loading cycles, the rate of pore water pressure builds up increases with an increase in strain amplitude. With an increase in relative density from 35 to $70 \%$, the development of pore water pressure declines over a given load cycle. For a specific relative density, the pore water pressure development rate for Patna soil is faster in comparison to Kanpur soil and Allahabad soil. This possibly due to the presence of coarse sand in the Patna soil than the Allahabad soil and Kanpur Soil. Similarly, Allahabad soil has faster pore water pressure development than Kanpur soil. This is due to the presence of $0 \%$ clay in Patna soil, $10 \%$ clay in Allahabad soil, and 16\% clay in Kanpur soil. Also, the silt percentage plays a crucial role for this type of behavior. Kanpur soil is 


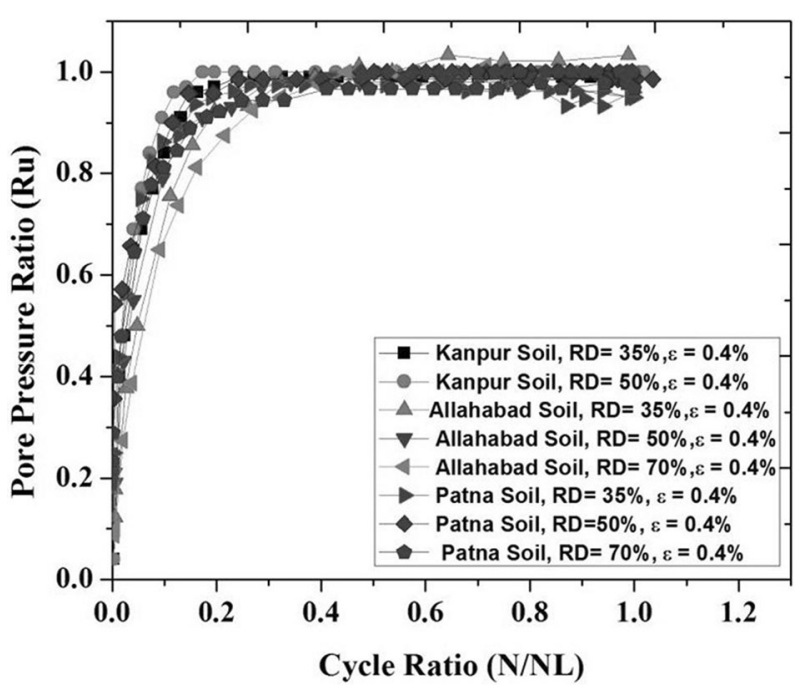

Fig. 9 Relationship between normalized pore pressure ratio for Kanpur soil, Allahabad soil and Patna soil (RD $=35 \%, 50 \%$ and $70 \%$, strain amplitude $=0.4 \%$ and frequency $=1 \mathrm{~Hz}$

having more than $80 \%$ silt, Allahabad soil is having $10 \%$ silt and Patna soil is having $5 \%$ silt. This indicates the effect of fines content plays an important role in the development of the pore water pressure during the cyclic loading. The present results of pore water pressure development were compared with strain controlled test results from previous studies. The result suggests that the silty soil is prone to liquefaction, but the percentage of clay controls the cyclic behavior of the silty clay soil. Kanpur soil has a higher percentage of clay (16\%) compared to Allahabad soil and Patna soil. Similarly, the Allahabad soil and Patna soil show lower liquefaction resistance than Kanpur soil. Patna soil exhibits a cyclic behaviour almost similar to Monterey sand, Ottawa sand, Saloni sand, Bhuj sand and Ahmedabad sand (Table 4). But, Allahabad soil is showing bit higher rate of pore water pressure development. This is due to presence of sand fraction with silt percentage of $10 \%$. The behavior of Allahabad soil well agrees with the results of Boulanger and Idriss [7], Kim et al. [22], Lade and Yamamuro [25], Naeini and Baziar [31] Zlatovic and Ishihara [48] that sandy soil with silt fraction is more vulnerable to liquefaction than clean sand and silty clay soil.

\section{Dynamic properties of soil}

Dynamic properties are one of the very important parameter of soil required for the analysis of seismic behavior of earth structures during dynamic loading such as earthquake, wind loading, blasting etc. In the present investigation the strain dependent dynamic soil properties of Kanpur soil, Allahabad soil and Patna soil has been studied in medium to large strain levels.

The dynamic soil properties for all the sites are given in Table 5. Figure 10a shows the variation of dynamic shear modulus with loading cycles for Kanpur soil tested with relative density of $35 \%$ and $50 \%$, effective confining pressure of $100 \mathrm{kPa}$ and applied frequency of $1 \mathrm{~Hz}$. The graph shows that for Kanpur soil, the dynamic shear modulus gradually decreases with an increase in the number of loading cycles. Thereafter, the 


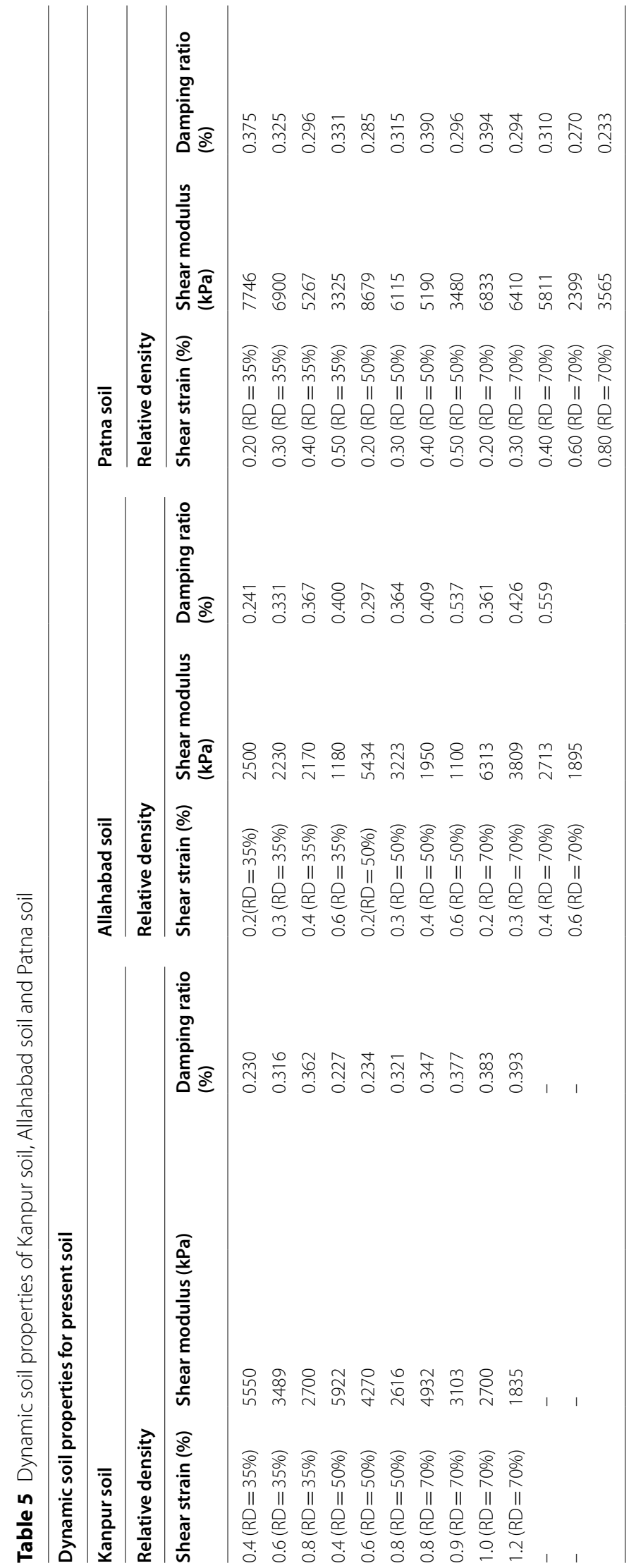




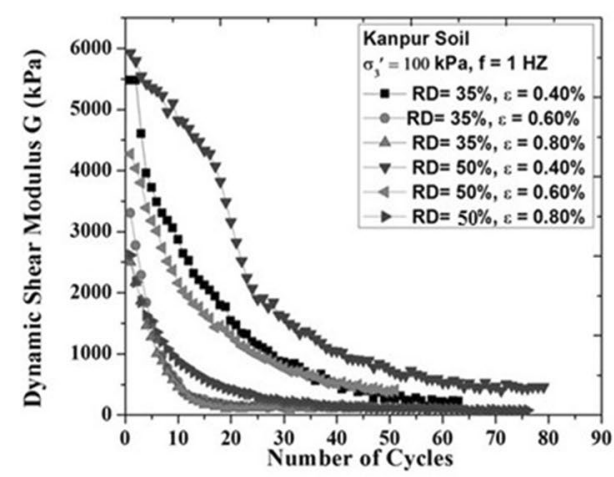

(a)

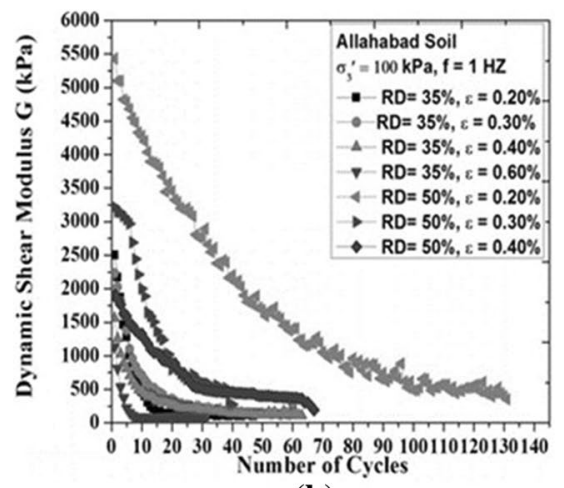

(b)

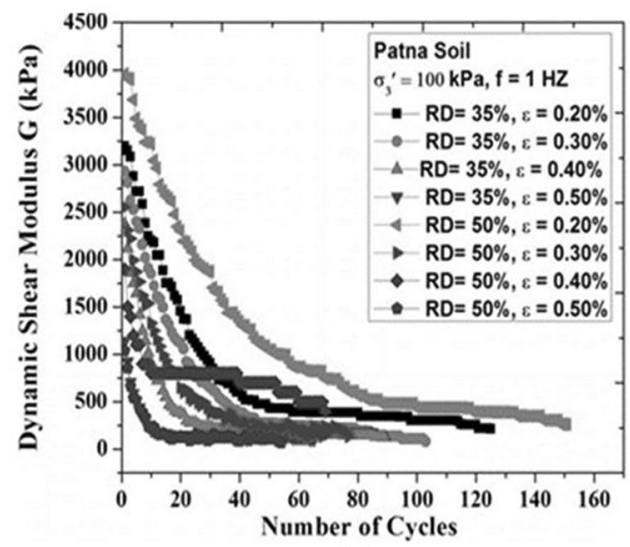

(c)

Fig. 10 Variation of shear modulus with number of loading cycle. a Kanpur cycle, RD $=35 \%, 50 \%$, strain amplitude $=0.40 \%, 0.60 \%, 0.80 \%$, effective confining pressure $=100 \mathrm{kPa}$, frequency $=1 \mathrm{~Hz}$. b Allahabad soil, $\mathrm{RD}=35 \%, 50 \%$, strain amplitude $=0.20 \%, 0.30 \%, 0.40 \%$, effective confining pressure $=100 \mathrm{kPa}$, frequency $=1 \mathrm{~Hz}$. c Patna soil, $\mathrm{RD}=35 \%, 50 \%$, strain amplitude $=0.20 \%, 0.30 \%, 0.40 \%$ and $0.50 \%$, effective confining pressure $=100 \mathrm{kPa}$, frequency $=1 \mathrm{~Hz}$

variation of shear modulus remains constant or asymptotic to the number of cycle axis. Also, the dynamic shear modulus value decreases with an increase in shear strain amplitude. A similar trend was also observed for Allahabad and Patna soils and is illustrated in Fig. 10b, c, respectively. The shear modulus varies from 1000 to $9000 \mathrm{kPa}, 1000 \mathrm{kPa}$ to $6000 \mathrm{kPa}$ and $1000 \mathrm{kPa}$ to $5000 \mathrm{kPa}$ for Kanpur soil, Allahabad soil and Patna soil, respectively. Typical diagram showing the comparison of variation of shear modulus for Kanpur soil, Allahabad soil and Patna soil is shown in Fig. 11a for frequency $1 \mathrm{~Hz}$, effective stress of $100 \mathrm{kPa}$ and axial shear strain amplitude of $0.4 \%$. It is noted that the dynamic shear modulus value increases from silty sand of Kanpur soil to coarse sand of Patna soil with average values for fine sand of Allahabad soil. The percent increase of shear modulus for Kanpur soil is about $6 \%$ to $200 \%$, $0 \%$ to $210 \%$ and $0 \%$ to $250 \%$ higher than the Allahabad soil for relative density of $35 \%, 50 \%$ and $70 \%$, respectively for an applied frequency of $1 \mathrm{~Hz}$ and effective confining pressure of $100 \mathrm{kPa}$. Likewise, the percentage increase of shear modulus for Allahabad soil is approximately $0 \%$ to $230 \%$, $2 \%$ to $210 \%$ and $0 \%$ to $260 \%$ higher than the Patna soil for relative density of $35-70 \%$, respectively for an applied frequency of $1 \mathrm{~Hz}$ and effective confining pressure of $100 \mathrm{kPa}$. The percent increase in dynamic shear modulus for Kanpur soil is about $0-250 \%, 0-210 \%$ 


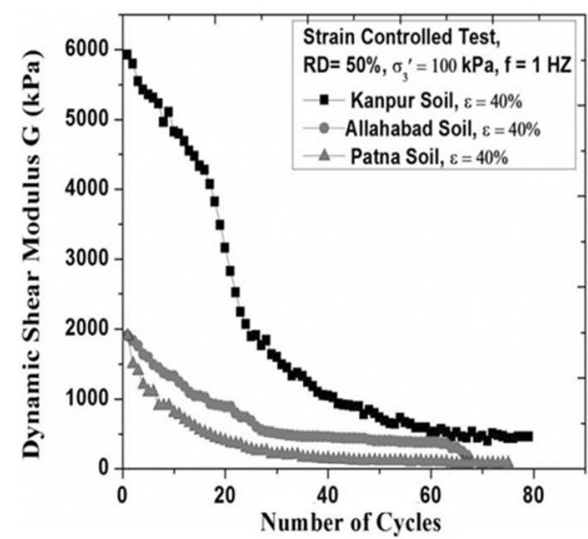

(a)

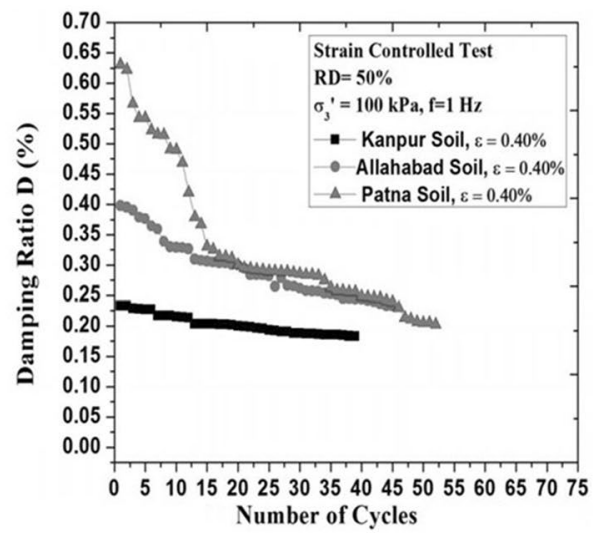

(b)

Fig. 11 a Variation of shear modulus with number of cycles for Kanpur, Allahabad and Patna soil (RD $=50 \%$, frequency $=1 \mathrm{~Hz}$, strain amplitude $=0.40 \%$ ). $\mathbf{b}$ Variation of damping ratio for Kanpur, Allahabad soil and Patna (RD $=50 \%$, effective confining pressure $=100 \mathrm{kPa}$, frequency $=1 \mathrm{~Hz}$, strain amplitude $=0.40 \%$ )

and $0-267 \%$ higher than Allahabad soil tested with effective confining pressure of $80 \mathrm{kPa}$ to $125 \mathrm{kPa}$, respectively for relative density of $50 \%$ and loading frequency of $1 \mathrm{~Hz}$. The percent increase of shear modulus for Kanpur soil is about $0-385 \%, 0-215 \%$ and $0-210 \%$ higher than Allahabad soil for soil sample tested with an applied frequency of $0.3 \mathrm{~Hz}$ to $1.0 \mathrm{~Hz}$, respectively, for relative density of $50 \%$ and effective confining pressure of $100 \mathrm{kPa}$. In general, Kanpur soil has a higher value of shear modulus than Allahabad soil and Patna soil. It may be due to that Kanpur soil is having more silt and clay fraction than Allahabad soil and Patna soil. Figure 12a shows the variation of damping ratio with number of loading cycles for Kanpur soil tested with relative density of $35 \%$ and $50 \%$, effective confining pressure of $100 \mathrm{kPa}$ and loading frequency of $1 \mathrm{~Hz}$. The graph shows that the dynamic shear modulus for Kanpur soil gently decreases with increase in the number of cycles. Thereafter, the variation of damping ratio remains constant or asymptotic to the number of cycle axis. For the same soil, the damping ratio value increases with shear strain amplitude. Similar trend has been observed for the Allahabad and Patna soil and is shown in Fig. 12b, c, respectively. The damping ratio varies from $0.1 \%$ to $0.47 \%, 0.2 \%$ to $0.78 \%$ and $0.2 \%$ to $0.88 \%$ for Kanpur soil, Allahabad soil and Patna soil respectively. Typical diagram showing the comparison of variation of damping ratio for Kanpur soil, Allahabad soil and Patna soil is shown in Fig. 11b (strain amplitude of $0.4 \%$, applied frequency $1 \mathrm{~Hz}$ and applied effective confine pressure, $100 \mathrm{kPa}$ ). It is noticed that the damping ratio value decreases from coarse sand of Patna soil to silty sand of Kanpur soil with intermediate values for fine sand of Allahabad soil. The percent increase of damping ratio for Patna soil is about $0-98 \%, 0-170 \%$ and $0-110 \%$ higher than the Allahabad soil for relative density of $35-70 \%$, respectively for the applied frequency of $1 \mathrm{~Hz}$ and effective confining pressure of $100 \mathrm{kPa}$. Similarly, the percent increase of damping ratio for Allahabad soil is about $0-91 \%, 0-136 \%$ and $0-67 \%$ higher than the Kanpur soil for relative density of 35-70\%, respectively for the applied frequency of $1 \mathrm{~Hz}$ and effective confining pressure of $100 \mathrm{kPa}$. The percent increase of damping ratio for Patna soil is about $0-87 \%, 2-101 \%$ and $0-178 \%$ higher than the Allahabad soil samples 


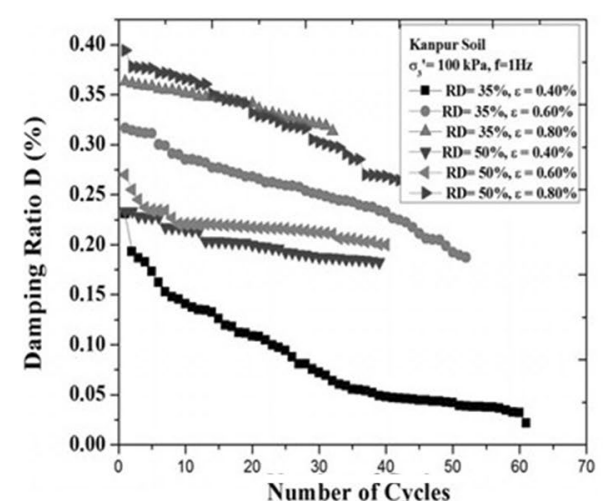

(a)

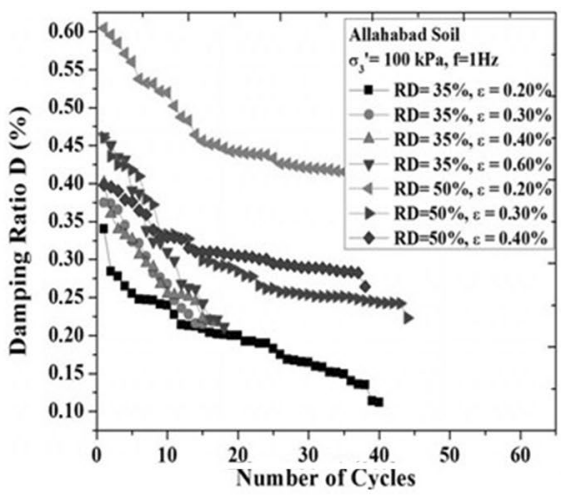

(b)

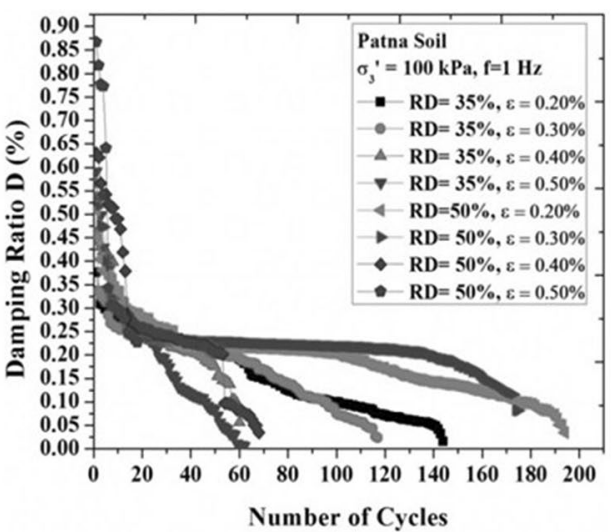

(c)

Fig. 12 Variation of damping ratio with relative density (a) Kanpur soil $(\mathrm{RD}=35 \%, 50 \%$, strain amplitude $=$ $0.40 \%, 0.60 \%, 0.80 \%$, effective confining pressure $=100 \mathrm{kPa}$, frequency $=1 \mathrm{~Hz}$. b Allahabad soil $(\mathrm{RD}=35 \%$, $50 \%$, strain amplitude $=0.20 \%, 0.30 \%, 0.40 \%$, effective confining pressure $=100 \mathrm{kPa}$, frequency $=1 \mathrm{~Hz}$ ). c Patna soil (RD $=35 \%, 50 \%$, strain amplitude $=0.20 \%, 0.30 \%, 0.40 \%$ and $0.50 \%$, effective confining pressure $=$ $100 \mathrm{kPa}$, frequency $=1 \mathrm{~Hz}$ )

tested with effective confining pressure of $80-125 \mathrm{kPa}$, respectively for the relative density of $50 \%$ and loading frequency of $1 \mathrm{~Hz}$. Similarly, the percent increase of damping ratio for Allahabad soil is about $0-70 \%, 0-136 \%$ and $0-191 \%$ higher than the Kanpur soil tested with effective confining pressure of $80-125 \mathrm{kPa}$, respectively for relative density of $50 \%$ and loading frequency of $1 \mathrm{~Hz}$. The percent increase in the damping ratio of Patna soil is $0-156 \%, 0-179 \%$ and $0-145 \%$ higher than Allahabad soil tested with an applied frequency of $0.3-1.0 \mathrm{~Hz}$. Similarly, the percent increase of damping ratio for Allahabad soil is about $0-130 \%, 0-190 \%$ and $0-136 \%$ higher than the Kanpur soil tested with an applied frequency of $0.3-1.0 \mathrm{~Hz}$, respectively for relative density of $50 \%$ and effective confining pressure of $100 \mathrm{kPa}$. In general, the damping ratio of Patna soil is higher than Allahabad and Kanpur soils. This may be due to presence of coarse sand in Patna city. The correlations between the axial shear strain and dynamic shear modulus, shear strain and damping ratio have been plotted for all soils. Typical plot for Kanpur soil and Allahabad soils are shown in Fig. 13. From Fig. 13, it is clearly noticed that there is a sharp increase in dynamic shear modulus and damping ratio values in the range of axial shear strain tested which indicates the degradation of shear modulus which is due to the 


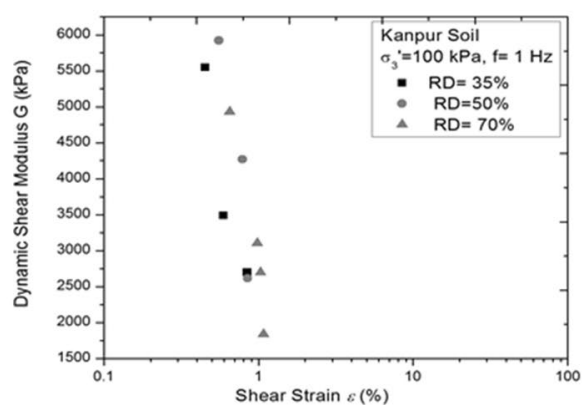

(a)

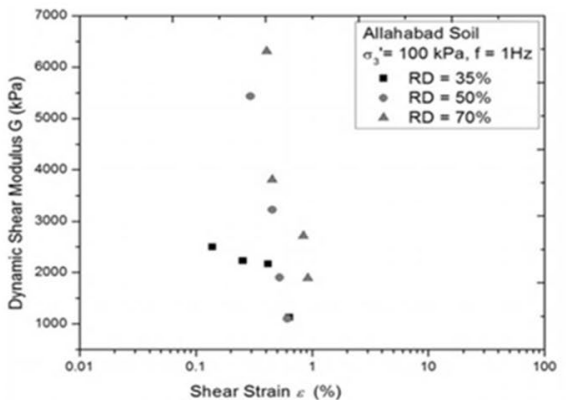

(c)

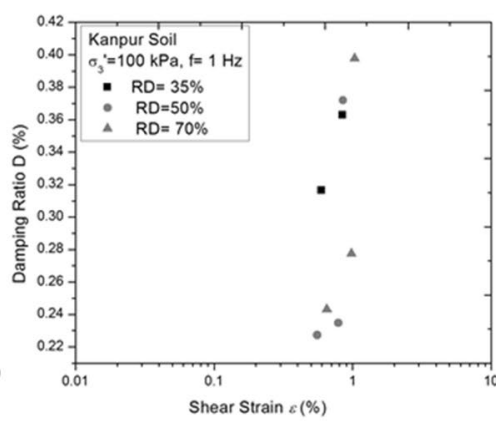

(b)

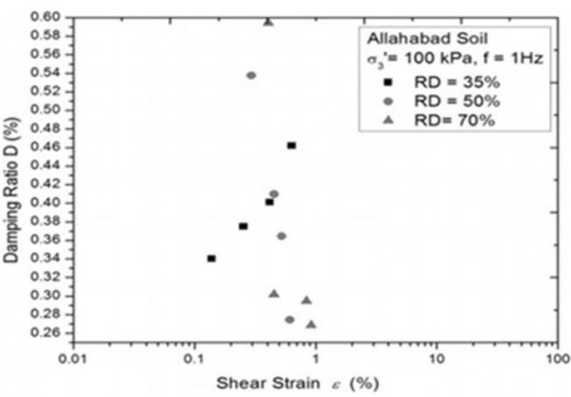

(d)

Fig. 13 a Shear modulus and shear strain relationship of Kanpur soil for different relative density. b Damping ratios and shear and strain relationship of Kanpur soil for different relative density. c Shear modulus and shear strain relationship of Allahabad soil for different relative density. $\mathbf{d}$ Damping ratios and shear strain relationship of Allahabad soil for different relative density

irrecoverable fabric arrangement of grains within soil specimen due to cyclic loading. The effect of relative density on dynamic shear modulus is significant in the range of axial shear strains tested. The plot shows the effect of relative density on shear modulus and damping ratio falls in a narrow zone of shear strain i.e. 0.4-1.0\%. Also, for Allahabad soil, the value of the shear module increases with relative density from 35 to $70 \%$. The effect of relative density on the dynamic shear modulus and damping ratio is almost

Table 6 Comparison of dynamic soil properties of present study with previous studies

\begin{tabular}{lllll}
\hline Authors & Soil type & $\begin{array}{l}\text { Relative } \\
\text { density } \\
\text { (\%) }\end{array}$ & Shear modulus (kPa) & Damping ratio (\%) \\
& & $75-89$ & $10,000,000-150,000,000$ & $0.7-1.5$ \\
\hline $\begin{array}{l}\text { Tatsuoka et al. (1978) } \\
\text { Kukusho (1980) }\end{array}$ & $\begin{array}{l}\text { Toyoura sand } \\
\text { Toyoura sand }\end{array}$ & - & $950-147,099.8$ & $0.01-0.30$ \\
$\begin{array}{l}\text { Vucetic and Dobry } \\
\text { (1991) }\end{array}$ & Sand + Fine content & & - & $0.04-0.25$ \\
Darendeli (2001) & Sandy Lean Clay-Silty & & $120,000-200,000$ & $0.08-0.17$ \\
& sand & & & \\
Govinda Raju (2005) & Bhuj sand & $8.9-80$ & $2500-12,000$ & $0.098-0.25$ \\
Govinda Raju (2005) & Ahmedabad sand & $30-70$ & $1000-14,200$ & $0.10-0.30$ \\
Govinda Raju (2005) & Assam sand & $20-75$ & $1500-7500$ & $0.09-0.22$ \\
Present Study & Kanpur soil & $30-70$ & $1800-6000$ & $0.20-0.40$ \\
Present Study & Allahabad soil & $30-70$ & $1100-7000$ & $0.24-0.60$ \\
Present Study & Patna soil & $30-70$ & $2000-9000$ & $0.23-0.40$ \\
\hline
\end{tabular}


similar for the axial shear strain range of $0.1-1.0 \%$. It is noticed that the dynamic shear modulus is more scattered than damping ratio, which indicates the relative density is having more effect on the shear modulus of Allahabad soil. Similar observation was noted for Patna soil.

The effect of confining pressure and frequency change on the dynamic soil properties of Kanpur soil, Allahabad soil and Patna soil were analyzed by plotting the axial strain amplitude with dynamic shear modulus and damping ratio. For Kanpur soil, the effect of effective confining pressure is more on dynamic shear modulus than damping ratio, whereas the applied frequency affects less to the shear modulus where it affects more to the damping ratio of Kanpur soil. Likewise, for Allahabad soil, the confining pressure affects more to the dynamic shear modulus than damping ratio. The applied frequency is having a similar effect on both the dynamic shear modulus and damping ratio of Allahabad soil. Similar observations were observed in Patna soil. This differential behavior between Kanpur soil, Allahabad soil and Patna soil may be due to the soil type and percentage of fines present in the soil.

The dynamic properties from the present study is compared with study by Darendeli [11], Vucetic and Dobry [45], Tatsuoka et al. [44], Govinda Raju and Sitharam [14] (Table 6). The result indicates the Toyoura sand produces higher shear modulus than Kanpur, Allahabad and Patna soil. The soil used by Darendeli [11] also shows higher shear modulus and damping ration than the present soil. This may be due to the tests were conducted at higher relative density. It indicates the soils of the present study area are more vulnerable to seismic damage at loose conditions. From the table, it is noticed that the shear modulus of Bhuj Sand and Ahmedabad sand are more than Kanpur soil, Allahabad soil and Patna soil for soil samples tested with same relative density. The dynamic shear modulus of Assam sand shows similar values as for Kanpur, Allahabad and Patna soil. This may be due to the presence of similar type of soil. Similarly, the damping ratio of Toyoura sand is higher than present soil. The damping ratio of Bhuj sand, Ahmedabad sand, and Assam sand are less than Kanpur soil and Allahabad soil and Patna soil. The sands of Allahabad, Patna and silty soils of Kanpur soil are mainly deposited due to the Himalayan fed rivers like Ganga, Yamuna, Son, which is having similar characteristics as Assam sand which is also deposited by mainly Himalayan

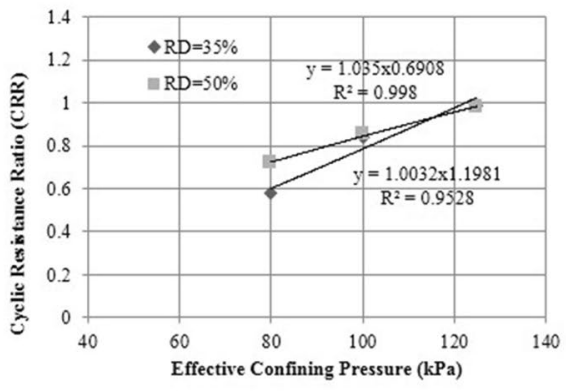

(a)

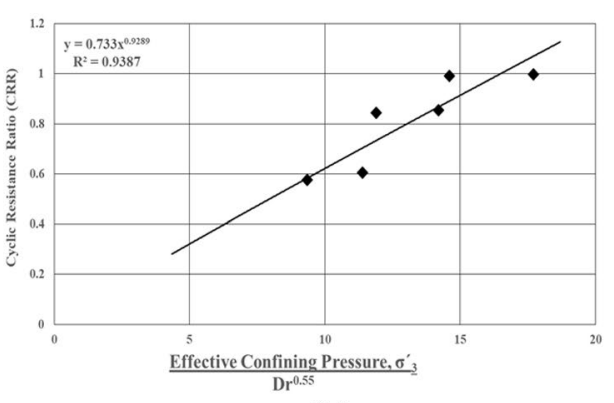

(b)

Fig. 14 a Variation of cyclic resistance ratio of Kanpur soil with effective confining pressure at various relative densities. $\mathbf{b}$ Variation of cyclic resistance ratio of Kanpur soil with effective confining pressure normalised to relative density 
origin rivers. The sands of Bhuj and Ahmedabad are of different origin. So it is behaving different dynamic behavior than Kanpur, Allahabad and Patna soil. This indicates the geology and age of the soil plays an important role in dynamic soil behavior and site specific liquefaction potential and dynamic soil characterization is more important for proper seismic hazard assessment.

\section{Correlations between cyclic resistance ratio (CRR) and effective confining pressure}

The variation of cyclic resistance ratio (CRR) with effective confining pressure have been plotted for Kanpur soil, Allahabad soil and Patna soil for relative density of 35\% -70\%. Typical diagram for Kanpur soil is shown in Fig. 14. The empirical correlation between CRR and the confining pressure for different relative density for Kanpur soil, Allahabad soil and Patna soil have been developed. The correlations are given in Eqs. (1-3) for Kanpur soil, Allahabad soil and Patna soil, respectively.

$$
\begin{aligned}
& \text { For Kanpur soil, CRR }=0.073\left(\mathrm{Dr} / \sigma_{3}^{\prime}\right)^{0.92}, \\
& \text { For Allahabad soil, CRR }=0.01\left(\mathrm{Dr} / \sigma_{3}^{\prime}\right)^{1.29} \text {, }
\end{aligned}
$$

For Patna soil, CRR $=0.19\left(\mathrm{Dr} / \sigma_{3}^{\prime}\right)^{1.30}$,

where CRR is the cyclic resistance ratio, Dr is the change in relative density and $\sigma_{3}^{\prime}$ is the effective confining pressure.

\section{Conclusions}

Undrained cyclic triaxial tests were carried out on Kanpur soil, Allahabad soil and Patna soil along Indo-Gangetic plain to study the liquefaction behavior, pore water pressure development and the dynamic properties of the soil.

From the present experimental investigations following conclusions are drawn:

(a) From the detailed soil classification, it can be observed that Kanpur soil (82\% silt and $18 \%$ sand) is mainly silty-sand soil, whereas the Allahabad soil ( $80 \%$ sand and $20 \%$ silt/clay) is mainly sandy soil and Patna soil ( $90 \%$ sand) is clean sand.

(b) The loading cycles required for initial liquefaction is about 15 to 800 cycles, 8 to 100 and 18 to 120 for IITK campus soil of Kanpur city, Jagadishpur soil of Allahabad city and IIT Patna campus soil of Patna city, respectively. Kanpur soils are more resistant to liquefaction compared to Allahabad soil and Patna soil. The shear modulus value of Kanpur soil is higher than Patna soil with intermediate values for Allahabad soil. Similarly, the damping ratio value of Patna soil is higher than Kanpur soil with intermediate values for Allahabad soil. This may be due to the presence of more silt fraction in Kanpur soil than Allahabad soil and Patna soil, which suggests the fines percentage plays a pivotal role in liquefaction potential and dynamic soil properties estimation.

(c) The effect of relative density, effective confining pressure and applied frequency on dynamic soil properties was studied. It is observed that relative density, effective confining pressure affects the shear modulus of alluvial soil more than the damp- 
ing ratio. The applied frequency affects more to the damping ratio than the shear modulus of alluvial soil.

(d) The result compared with the previous strain controlled test results which suggests that the soil type, fines content and the geological origin plays an important role in cyclic behavior and dynamic soil properties. The sandy soil having more than $10 \%$ silt is more prone to liquefaction than clean sand and pure silty soil. The soil of similar geological origin like Kanpur, Allahabad, Patna and Assam sand shows a similar kind of cyclic behavior as they all are deposited by Himalayan fed rivers, whereas the soils from Bhuj, Ahmedabad are or different origin showing different cyclic behavior with same soil characteristics. This implies site specific study is more required for proper seismic hazard estimation.

(e) This study presents a new empirical relationship for predicting the liquefaction resistance of alluvial soil of Indo-Gangetic Plain in terms CRR. The empirical equation is based on the cyclic triaxial test results and shows a linear correlation between the relative density, effective confining pressure and CRR.

\section{Abbreviations}

CRR: Cyclic resistance ratio; D: Damping ratio; Dr: Change in relative density; f: Frequency; N: Number of loading cycles; $\mathrm{NL}$ : Cumulative number of cycles; $\mathrm{p}^{\prime}$ : Mean effective stress; q: Deviatric stress; Ru: Pore pressure ratio; $\varepsilon$ : Axial shear strain; $\sigma_{3}^{\prime}$ : Effective stress.

\section{Acknowledgements}

The research work presented in this paper was financially supported by Department of Science and Technology (DST), Government of India.

\section{Authors' contributions}

SPN carried out field surveys and all the Geotechnical testing. SPN drafted this manuscript, while NRP and JNM gave valuable suggestions and corrected the paper. All authors read and approved the final manuscript.

\section{Funding}

This study was funded by SERC Division, Department of Science and Technology(DST), Government of India.

\section{Declarations}

Competing interests

The authors declare that they have no competing interests.

Received: 31 May 2017 Accepted: 9 August 2021

Published online: 04 January 2022

\section{References}

1. ASTM D2487-11 Standard Practice for Classification of Soils for Engineering Purposes (Unified Soil Classification System). American Society of Testing and Materials, West Conshohocken, Pennsylvania, USA

2. ASTM D 5311-92 (Reapproved 1996) Standard test method for laod controlled cyclic triaxial strength of soil. American Society of Testing and Materials West Conshohocken Pennsylvania, USA

3. ASTM D 3999-91 Standard test method for the determination of modulus and damping properties of soils using the cyclic triaxial apparatus, Annual Book of ASTM standards, Vol. 04-08

4. Bayat M, Bayat E, Aminpour H, Salarpour A (2014) Shear strength and pore-water pressure characteristics of sandy soil mixed with plastic fine. Ara J Geosc 7(3):1049-1057

5. Benghalia Y, Bouafia A, Canou J, Dupla JC (2015) Liquefaction susceptibility study of sandy soils: effect of low plastic fines. Ara Geosci 8(2):605-618

6. Belkhatir M, Arab A, Schanz T, Missoum H, Della N (2011) Laboratory study on the liquefaction resistance of sand-silt mixtures: effect of grading characteristics. Granular Matter 13(5):599-609

7. Boulanger RW and Idriss IM (2005) New criteria for distinguishing between silts and clays that are susceptible to liquefaction versus cyclic failure. In: 25th Annual USSD Conference, Salt Lake City, Utah, June 6-10: 357-366

8. Castro G (1975) Liquefaction and cyclic mobility of saturated sands. J Geotech Eng 101(6):551-569 
9. Castro G (1977) Factors affecting liquefaction and cyclic mobility. J Geotech Eng 103(6):501-516

10. Dash HK, Sitharam TG (2016) Effect of frequency of cyclic loading on liquefaction and dynamic properties of saturated sand. Int J Geotech Eng 10(5):487-492

11. Darendeli M (2001) Development of a new family of normalized modulus reduction and material damping. Doctoral thesis, University of Texas

12. Dobry R, Ladd RS, Chang RM, and Powell D (1982) Prediction of pore water pressure build up and liquefaction of sands during earthquake by cyclic strain methods. NBS Building Science Series 138, Washington, DC: 1-150

13. Dobry R (1985) Liquefaction of soils during earthquakes. Committee on Earthquake Engineering, Commission on Engineering and Technical Systems. National Research Council, National Academy Press, Washington, D.C

14. Govinda Raju L, Sitharam TG (2005) Liquefaction and Dynamic properties of sandy soils. Ph.D Thesis, Indian Institute of Science, Bangalore, India

15. Ishihara K, Tatsuoka F, Yasuda S (1975) Undrained deformation and liquefaction of sand under cyclic stresses. Soils Found 15(1):29-44

16. Ishihara K (1996) Soil behavior in earthquake Geotechnics. Oxford University Press Inc., New York

17. I wasaki T, Arakawa T, Tokida KI (1984) simplified procedures for assessing soil liquefaction during earthquakes. Soil Dyn Earth Eng 3:49-58

18. Iwasaki T, Tatsuoka F (1977) Effects of grain size and grading on dynamic shear moduli of sands. Soils Found 5:1-68

19. Iwasaki T, Arakawa T, Tokida KI (1984) Simplified procedures for assessing soil liquefaction during earthquakes. Soil Dyn Earthq Eng 3:49-58

20. Jishnu RB, Naik SP, Patra NR, Malik JN (2013) Ground response analysis of Kanpur soil along Indo-Gangetic Plains. Soil Dyn Earthq Eng 51:47-57

21. Kaya Z, Erken A (2015) Cyclic and post-cyclic monotonic behavior of Adapazari soils. Soil Dyn Earthq Eng 77:83-96

22. Kim UG , Zhuang L, Kim D, Lee J (2016) Evaluation of cyclic shear strength of mixtures with sand and different types of fines. Marine Geo Geotech 1-9

23. Krim A, Arab A, Bouferra R, Sadek M, Shahrour I (2016) Characteristics of cyclic shear behavior of sandy soils: a laboratory study. A J Sci Eng 41(10):3995-4005

24. Kundu A, Patra NR, Bandopadhaya S, Reddy GR (2021) Static and dynamic characterization and response analysis of soils from Northern India. SN App Sci 3(2):1-15

25. Lade PV, Yamamuro JA (1997) Effects of non-plastic fines on static liquefaction of sands. Can Geotech J 34:918-928

26. Law KT, Cao YL, He GN (1990) An energy approach for assessing seismic liquefaction potential. Can Geotech J 27:320-329

27. Malik JN, Naik, SP, Sahoo, S, Okumura, K and Mohanty, A (2016) Paleoseismic evidence of the CE 1505 (?) and CE 1803 earthquakes from the foothill zone of the Kumaon Himalaya along the Himalayan Frontal Thrust (HFT) India. Tectonophysics

28. Mohanty S (2014) Dynamic characterization and analysis of pond ash embankments from Talcher, Panki and Panipat Sites of India. PhD Thesis, IIT Kanpur

29. Mohanty S, Patra NR (2014) Cyclic behavior and liquefaction potential of Indian pond ash located in seismic zones III and IV. J Mater Civ Eng 26(7):06014012

30. Muley P, Maheshwari BK, Paul DK (2012) Effect of fines on liquefaction resistance of solani sand. In: Proc. of 15th World Conference on Earthquake Engineering, Lisbon, Portugal $2012 \mathrm{Sep}$

31. Naeini SA, Baziar MH (2004) Effect of fines content on steady state strength of mixed and layered samples of sand. Soil Dyn Earthq Eng 24:181-187

32. Naik SP (2015) Active Fault and Paleoseismic studies along Himalayan Frontal Thrust, Central Himalaya: Implication towards evaluation of Liquefaction Potential of Alluvial soils of Indo-Gangetic Plain. PhD Thesis, IIT Kanpur

33. Naik SP, Kundu A, Patra NR, Bandopadhaya S, Reddy GR (2019) Earthquake response analysis of soils from Rudrapur and Khatima Sites Adjacent to Himalayan Frontal Thrust (HFT) using field and laboratory-derived dynamic soil properties. J Earthq Eng 1-31

34. Peck RB (1977) Liquefaction potential: science versus practice. J Geotech Eng 105(GT3):393-398

35. Raghunandan ME, Juneja A (2010) Behaviour of soil under cyclic loading. In: Indian Geotechnical Conference, IGS Mumbai Chapter \& IIT Bombay. 16:195-198

36. Seed HB, Idriss IM (1971) Simplified procedure for evaluating soil liquefaction potential. J Soil Mech Found 97:1249-1274

37. Seed HB, Idriss IM, Makdisi F, Banerjee N (1975) Representation of irregular stress time histories by equivalent uniformstress series in liquefaction analyses. Rep. No. UCB/EERC 75-29, Earthquake Engrg. Res. Ctr., University of California, Berkeley, California

38. Seed HB (1987) Design problems in soil liquefaction. J Geotechl Eng 103(8):827-845

39. Sukhija BS, Rao MN, Reddy DV, Nagabhushanam P, Kumar D, Lakshmi BV, Sharma P (2002) Palaeoliquefaction evidence of prehistoric large/great earthquakes in North Bihar, India. Curr Sci. 1019-25

40. Vijayasri T (2017) Dynamic characterization of Renusagar pond ash embankment with and without geotextiles. PhD Thesis, IIT Kanpur

41. Vijayasri T, Patra NR, Raychowdhury P (2016) Cyclic behavior and liquefaction potential of Renusagar pond ash reinforced with geotextiles. J Mat Civil Eng 28(11):04016125

42. Troncoso JH (1990) Failure risks of abandoned tailings dams. In: Proc. of Int. Symp. On Safety and Rehabilitation of Tailing Dams. Int Com on Large Dams Paris, pp. 82-89

43. Talaganov KV (1996) Stress strain transformations and liquefaction of sands. Soil Dyn Earth Eng 15:411-418

44. Tatsuoka F, Iwasaki T, Takagi Y (1978) Hysteric damping of sand under cyclic loading and its relation to shear modulus. Soils Found 18:25-40

45. Vucetic M, Dobry R (1996) Effects of soil plasticity on cyclic response. J Geotech Eng 117(1):89-107

46. Wang JN, Kavazanjian E (1989) Pore pressure development during non-uniform cyclic loading. Soils Found 29(2):1-14

47. Youd TL (1972) Compaction of sands by repeated shear straining. J Soil Mech Found 124(9):709-725 
48. Zlatovic S and Ishihara K (1995) On the influence of non-plastic fines on residual strength. In: Proc. Of the First Int. Conf. on Earthquake Geotechnical Engineering, Tokyo, 14-16 November

\section{Publisher's Note}

Springer Nature remains neutral with regard to jurisdictional claims in published maps and institutional affiliations. 